\title{
The expression of intercellular adhesion molecule-1 and the $\beta 1$-integrins in asthma
}

\author{
N.D. Manolitsas*, C.J. Trigg*, A.E. McAulay**, J.H. Wang*, \\ S.E. Jordan**, A.J. D'Ardenne**, R.J. Davies*
}

The expression of intercellular adhesion molecule-1 and the $\beta 1$-integrins in asthma. N.D. Manolitsas, C.J. Trigg, A.E. McAulay, J.H. Wang, S.E. Jordan, A.J. D'Ardenne, R.J. Davies. CERJ Journals Ltd 1994.

ABSTRACT: Expression of intercellular adhesion molecule-1 (ICAM-1) appears to be important to the development of bronchial hyperresponsiveness and eosinophilia in Ascaris sensitized monkeys. Beta ${ }_{1}$-integrins are expressed on epithelial cells, and may contribute to adherence of epithelial cells to the basement membrane. The aim of this study was to determine whether adhesion receptor expression was altered in human asthmatic bronchial epithelium.

Using monoclonal antibody staining, we have examined the expression of ICAM-1 and the $\alpha_{1}-\alpha_{6}$-subunits of the $\beta_{1}$-integrin family in bronchial mucosal biopsies from 33 asthmatic and 13 nonasthmatic subjects.

The epithelium was positive for ICAM-1 in 26 out of 33 asthmatics, although negative in all 13 nonasthmatics. ICAM-1 expression was not associated with bronchial

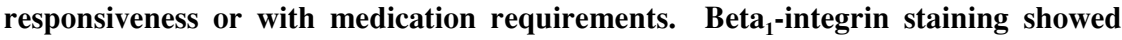
that $\alpha_{2}-, \alpha_{3}-$ and $\alpha_{6}-$ subunits stained the epithelium in all cases. Alpha ${ }_{4}$ staining was weakly positive in the epithelium in five asthmatics. Alpha ${ }_{5}$ staining was weak in asthmatics and normals. Alpha ${ }_{4}$ and $\alpha_{6}$ - subunits also stained inflammatory cells.

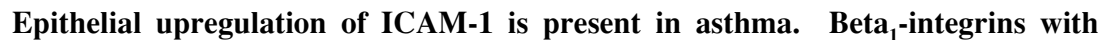
$\alpha_{2}, \alpha_{3^{-}}$and $\alpha_{6}$-subunits appear to be constitutively expressed in bronchial epithelium.

Eur Respir J., 1994, 7, 1439-1444.
Depts of *Respiratory Medicine and **Histopathology, St Bartholomews Hospital, London, UK.

Correspondence: R.J. Davies Dept of Respiratory Medicine St Bartholomews Hospital London EC1A 7BE UK

Keywords: Adhesion receptors $\alpha$-subunits

asthma

$\beta_{1}$-integrins

bronchial hyperresponsiveness intercellular adhesion molecule-1

Received: August 231993

Accepted after revision April 201994
Bronchial mucosal inflammation is a feature demonstrated in biopsy studies of all but the mildest forms of asthma [1-6]. The mechanism by which eosinophils, lymphocytes and other inflammatory cells enter the airway mucosa is not completely understood: however, it now appears that adhesion receptors have a role to play in initiating and maintaining this complex cellular interaction. Three families of adhesion receptors are recognized; the immunoglobulin superfamily, the integrin family and the selectins [7]. Of these, we have examined the expression of intercellular adhesion molecule-1 (ICAM1) and the $\alpha_{1}-\alpha_{6}$-subunits of the $\beta_{1}$-integrin family in the bronchial epithelium both of asthmatic and nonasthmatic subjects.

ICAM- 1 is a single chain glycoprotein, composed of a short cytoplasmic domain, a hydrophobic transmembrane domain and five immunoglobulin-like extracellular domains. It has a wide distribution on haemopoietic and nonhaemopoietic cells, and is upregulated in inflammation. Cytokines known to upregulate ICAM-1 include interferon- $\gamma$ (IFN- $\gamma$ ), tumour necrosis factor (TNF) and interleukin 1 (IL-1). Vascular endothelium shows the strongest expression. The major ligands for ICAM-1 are the $\beta_{2}$-integrins, lymphocyte function-associated antigen (LFA-1; present on leucocytes) and Mac-1 (on neutrophils, monocytes and natural killer cells) [8]. Endothelial expression of ICAM-1 has been shown in association with T-lymphocyte, neutrophil and eosinophil chemotaxis into areas of inflammation, indicating that the interaction with the $\beta_{2}$-integrins assists in the passage of leucocytes across an endothelial barrier into a site of inflammation $[7,9,10]$. Further interest in the role of ICAM-1 in the pathogenesis of asthma was generated by the finding that intravenous injection of monoclonal antibodies to ICAM-1 in sensitized monkeys, prior to multiple allergen inhalations, could block or attenuate the increased bronchial hyperresponsiveness and reduce the number of eosinophils in bronchoalveolar lavage specimens [11].

The beta ${ }_{1}\left(\beta_{1}\right)$ integrins are transmembrane glycoproteins, which are heterodimers comprising one of six different $\alpha$-subunits in association with a $\beta_{1}$-subunit [12]. These were previously known as the very late activation molecules (VLA 1-6) [13]. Their ligands include the connective tissue components laminin, collagen and 
Table 1. - Adhesion receptors studied with clones and sources of primary antibodies used

\begin{tabular}{|c|c|c|c|c|}
\hline Sub-units & Name & Ligands & $\begin{array}{c}\text { MoAb } \\
\text { used }\end{array}$ & $\begin{array}{l}\text { Manufacturer (UK } \\
\text { supplier) }\end{array}$ \\
\hline$\alpha_{1} \beta_{1}$ & VLA-1 & Laminin, collagen & $\mathrm{TS} 2 / 7$ & $\begin{array}{l}\text { T-cell Sciences (Laboratory } \\
\text { Impex Ltd, Middlesex, UK) }\end{array}$ \\
\hline$\alpha_{2} \beta_{1}$ & VLA-2 & Laminin, collagen & Gi9 & $\begin{array}{l}\text { Immunotech (The Binding Site, } \\
\text { Birmingham, UK) }\end{array}$ \\
\hline$\alpha_{3} \beta_{1}$ & VLA-3 & $\begin{array}{l}\text { Fibronectin, } \\
\text { laminin, collagen }\end{array}$ & P1B5 & $\begin{array}{l}\text { Chemicon Int., } \\
\text { (London, UK) }\end{array}$ \\
\hline$\alpha_{4} \beta_{1}$ & VLA-4 & $\begin{array}{l}\text { Fibronectin, } \\
\text { VCAM-1 }\end{array}$ & $\mathrm{HP} 2 / 1$ & Immunotech \\
\hline$\alpha_{5} \beta_{1}$ & VLA-5 & Fibronectin, & SAM1 & Immunotech \\
\hline$\alpha_{6} \beta_{1}$ & VLA-6 & Laminin & GoH3 & Immunotech \\
\hline ICAM-1 & - & LFA1, Mac-1 & $84 \mathrm{H} 10$ & Serotec (Oxford, UK) \\
\hline
\end{tabular}

VLA: very late activation molecule; ICAM-1: intercellular adhesion molecule-1; VCAM: vascular cell adhesion molecule-1; MoAb: monoclonal antibody; LFA-1: lymphocyte function-associated antigen-1.

fibronectin [7-14] (table 1), each of which is found in the epithelial basement membrane, indicating a possible role in cell-cell and cell-matrix interaction. In more severe asthmatics, epithelial desquamation is seen in the bronchus [3], although this is more contentious in mild asthma $[5,15,16]$. Furthermore, $\alpha_{4} \beta_{1}$-integrin is expressed on inflammatory cells, providing an alternative mechanism for adherence to the vascular endothelium via the ligand vascular cell adhesion molecule-1 (VCAM-1). Our hypothesis was that altered epithelial expression of the $\beta_{1}$-integrins might be expected in mild asthma; we might expect to find increased expression due to increased epithelial activity and turnover. Alternatively, it might also be possible that decreased expression might occur, due to epithelial damage and disruption.

\section{Materials and methods}

The research protocol was approved by the District Research Ethics Committee of St Bartholomews Hospital.

\section{Study population}

Thirty four mild to moderate asthmatics were studied (see table 2 for subject characteristics). Each had a clinical history consistent with asthma [17], and was demonstrated to have bronchial hyperresponsiveness to histamine with a $20 \%$ fall in the forced expiratory volume in one second $\left(\mathrm{FEV}_{1}\right)$ at a histamine concentration less than 2 $\mathrm{mg} \cdot \mathrm{ml}^{-1}\left(\mathrm{PC}_{20} \mathrm{FEV}_{1}\right)$ using a Devilbiss 646 nebulizer (tidal breathing method as described by BENNETT and DAVIES [18]). Nebulizer output was measured as $0.83 \pm 0.06$ $\mathrm{ml} \cdot 2 \mathrm{~min}^{-1}$. All subjects had been nonsmokers for at least $2 \mathrm{yrs}$, and had received no treatment other than inhaled albuterol over the previous 6 months. None had a history of respiratory tract infection over the month prior to the study.

Thirteen normal subjects with no clinical history of asthma were studied. Each had an $\mathrm{FEV}_{1}$ within the normal predicted range on spirometry and normal bronchial responsiveness to histamine $\left(\mathrm{PC}_{20} \mathrm{FEV}_{1}>4 \mathrm{mg} \cdot \mathrm{ml}^{-1}\right)$. Fibreoptic bronchoscopy

Five to 10 days following histamine bronchial provocation testing, each subject underwent fibreoptic bronchoscopy using an Olympus BF20 bronchoscope (Keymed, Southend, UK). The procedure was carried out in accordance with the guidelines of the American Thoracic Society for the study of asthmatics [19]. Asthmatic subjects received $2.5 \mathrm{mg}$ nebulized albuterol with their premedication (50-100 mg pethidine, $12.5 \mathrm{mg}$ stemetil and $0.6 \mathrm{mg}$ atropine intramuscularly). Topical anaesthesia was achieved with 2 and $4 \%$ lignocaine solution. Biopsies were taken using cup forceps from segmental carinae of the right upper and middle lobes.

\section{Immunohistology}

Biopsies were embedded in OCT compound (Agar, UK) and frozen in liquid nitrogen. They were subsequently sectioned at $5 \mu \mathrm{m}$ and fixed in acetone. Staining was carried out using an avidin-biotin complex immunoperoxidase method [20], using a Dako rabbit anti-mouse secondary antibody and a Vector rabbit and rat secondary antibody (for $\alpha_{6} \beta_{1}$-integrin). Endogenous peroxidase was blocked with $15 \%$ hydrogen peroxide in methanol after application of the first antibody. Peroxidase was developed with diaminobenzidine tetrahydrochloride (DAB). Sections were counterstained with Meyer's haematoxylin. For negative controls, the primary antibodies were omitted and replaced by normal mouse serum as a control for the mouse mono-clonals as described previously [21]. Rat serum was used to control for $\alpha_{6} \beta_{1}$-integrin (rat immunoglobulin-2 (IgG2 $\alpha$ ). (The sources of the primary antibodies are listed in table 1). Grading of ICAM-1 expression in epithelium was carried out using a scale of $0-3$ by two independent observers without clinical information about the subjects. Expression was only graded in epithelium where more than a basal cell layer was present. Grading was determined not only by colour 
Table 2. - Asthmatic subject characteristics and results of staining for ICAM-1 in bronchial epithelium

\begin{tabular}{|c|c|c|c|c|c|c|c|c|}
\hline $\begin{array}{l}\text { Subject } \\
\text { No. }\end{array}$ & Sex & $\begin{array}{l}\text { Age } \\
\text { yrs }\end{array}$ & $\begin{array}{l}\mathrm{FEV}_{1} \\
\% \text { pred }\end{array}$ & $\begin{array}{c}\mathrm{PC}_{20} \mathrm{FEV}_{1} \\
\mathrm{mg} \cdot \mathrm{ml}^{-1}\end{array}$ & $\begin{array}{c}\text { Duration } \\
\text { of asthma } \\
\text { yrs }\end{array}$ & $\begin{array}{c}\text { Doses } \\
\beta 2-\mathrm{ag} / 7 \text { days }^{-1}\end{array}$ & Atopy* & $\begin{array}{c}\text { ICAM-1 } \\
\text { grade } \\
0-3 \\
\end{array}$ \\
\hline 1 & F & 30 & 81 & 0.050 & 20 & 13 & + & 1 \\
\hline 2 & M & 22 & 69 & 0.046 & 8 & 18 & + & 3 \\
\hline 3 & M & 25 & 105 & 0.250 & 25 & 8 & + & 3 \\
\hline 4 & $\mathrm{~F}$ & 25 & 96 & 0.990 & 20 & 2 & + & 0.5 \\
\hline 5 & F & 28 & 87 & 0.043 & 5 & 8 & + & 1.5 \\
\hline 6 & F & 33 & 60 & 0.016 & 3 & 14 & + & 2.5 \\
\hline 7 & F & 24 & 65 & 0.072 & 5 & 8 & + & 0 \\
\hline 8 & $\mathrm{~F}$ & 27 & 89 & 0.072 & 3 & 11 & + & 0.5 \\
\hline 9 & M & 32 & 106 & 0.030 & 20 & 13 & + & 2 \\
\hline 10 & $\mathrm{~F}$ & 24 & 86 & 0.160 & 18 & 0 & + & 1.5 \\
\hline 11 & M & 33 & 97 & 0.820 & 20 & 11 & + & 3 \\
\hline 12 & M & 19 & 108 & 0.260 & 2 & 31 & + & 0 \\
\hline 13 & $\mathrm{~F}$ & 41 & 78 & 0.024 & 10 & 8 & + & 2.5 \\
\hline 14 & F & 24 & 107 & 0.076 & 14 & 24 & + & 1.0 \\
\hline 15 & F & 23 & 71 & 0.160 & 8 & 0 & - & NS \\
\hline 16 & M & 42 & 93 & 0.031 & 18 & 2 & + & 1 \\
\hline 17 & M & 43 & 67 & 0.024 & 18 & 11 & + & 3 \\
\hline 18 & M & 27 & 112 & 0.110 & 13 & 9 & + & 3 \\
\hline 19 & M & 36 & 101 & 0.440 & 25 & 16 & + & 1.5 \\
\hline 20 & M & 32 & 113 & 0.083 & 25 & 3 & + & 0 \\
\hline 21 & $\mathrm{~F}$ & 24 & 93 & 0.042 & 10 & 16 & + & 0.5 \\
\hline 22 & F & 26 & 88 & 0.340 & 10 & 0 & + & 0 \\
\hline 23 & M & 34 & 119 & 0.530 & 7 & 8 & + & 0.5 \\
\hline 24 & $\mathrm{~F}$ & 41 & 105 & 1.220 & 20 & 18 & + & 0 \\
\hline 25 & $\mathrm{~F}$ & 27 & 71 & 0.045 & 15 & 9 & + & 1.0 \\
\hline 26 & $\mathrm{~F}$ & 42 & 100 & 0.520 & 6 & 16 & - & 1.0 \\
\hline 27 & $\mathrm{~F}$ & 30 & 91 & 0.028 & 6 & 44 & + & 0 \\
\hline 28 & M & 20 & 103 & 0.400 & 10 & 2 & + & 0 \\
\hline 29 & $\mathrm{~F}$ & 24 & 93 & 0.105 & 21 & 7 & + & 0.5 \\
\hline 30 & M & 34 & 106 & 0.085 & 15 & 34 & + & 0.5 \\
\hline 31 & M & 28 & 64 & 0.044 & 25 & 25 & + & 0.5 \\
\hline 32 & $\mathrm{~F}$ & 33 & 99 & 0.140 & 14 & 10 & + & 0.5 \\
\hline 33 & M & 35 & 43 & 0.015 & 3 & 62 & + & 1.5 \\
\hline 34 & M & 40 & 78 & 0.021 & 12 & 19 & + & 0.5 \\
\hline \multicolumn{2}{|c|}{$\begin{array}{l}\text { Mean } \\
\text { (95\% range) }\end{array}$} & $\begin{array}{c}30 \\
( \pm 13)\end{array}$ & $\begin{array}{c}89.5 \\
( \pm 36.4)\end{array}$ & $\begin{array}{c}0.215 \\
( \pm 0.601)\end{array}$ & $\begin{array}{c}13.3 \\
( \pm 14.8)\end{array}$ & $\begin{array}{c}14.1 \\
( \pm 26.7)\end{array}$ & & \\
\hline
\end{tabular}

ICAM-1: intercellular adhesion molecule-1; $\mathrm{M}$ : male; $\mathrm{F}$ : female; $\mathrm{FEV}_{1}$ : forced expiratory volume in one second; $\mathrm{PC}_{20} \mathrm{FEV}$ : provocative concentration producing a $20 \%$ fall in $\mathrm{FEV}_{1}$; NS: no sample. $\beta_{2}$-ag: number of $100 \mu \mathrm{g}$ doses of albuterol taken by metered-dose inhaler over the seven days prior to bronchoscopy. ICAM-1 grading: mean grade from 2 biopsies. *: atopy is defined by a positive skin prick test to Dermatophagoides pteronyssinus, grass pollen or Aspergillus fumigatus.

intensity but also by distribution of staining.

\section{Results}

The results of epithelial staining, comparing asthmatic and nonasthmatic bronchial biopsies, are summarized in table 3. As the monoclonal antibodies for $\alpha_{4}$-subunits were initially in short supply, not all of the biopsies were stained using these monoclonals. The staining was similar for the $\alpha_{2^{-}}, \alpha_{3}-$ and $\alpha_{6}$-subunits, with positive epithelial reactivity in all biopsies, particularly in the basal epithelium for the $\alpha_{2}$ - and $\alpha_{6}$-subunits (figs. $1-3$ ). There was a little nonspecific staining with rat serum, which did not follow the same distribution as the staining for $\alpha_{6} \beta_{1}$-integrin. Mouse serum controls were all negative. Reactivity for the $\alpha_{4}$-subunit was negative, with the exception of five asthmatics with weak epithelial staining for the $\alpha_{4}$-subunit. Staining for the $\alpha_{4}$-subunit also highlighted inflammatory cells infiltrating bronchial epithe- lium and connective tissue (fig. 4). Staining for the $\alpha_{5^{-}}$ subunit was weak both in asthmatics and normals. There were no significant differences between asthma-tic and normal subjects with regard to integrin staining, nor was there any correlation between the weak epithelial stain-

Table 3. - Epithelial expression of $\beta_{1}$-integrins in asthmatics and normals

\begin{tabular}{lll}
\hline$\alpha$-subunit & Asthmatics & Nonasthmatics \\
\hline$\alpha_{1} \beta_{1}$ & $0 / 34$ & $0 / 13$ \\
$\alpha_{2} \beta_{1}$ & $34 / 34$ (basal) & $13 / 13$ (basal) \\
$\alpha_{3} \beta_{1}$ & $34 / 34$ & $13 / 13$ \\
$\alpha_{4} \beta_{1}$ & $5 / 20^{*}$ (weak) & $0 / 13$ \\
$\alpha_{5} \beta_{1}$ & Weak & Weak \\
$\alpha_{6} \beta_{1}$ & $34 / 34$ (basal) & $13 / 13$ (basal) \\
\hline
\end{tabular}

*: not all specimens stained, due to initial short supply of monoclonal antibody. 


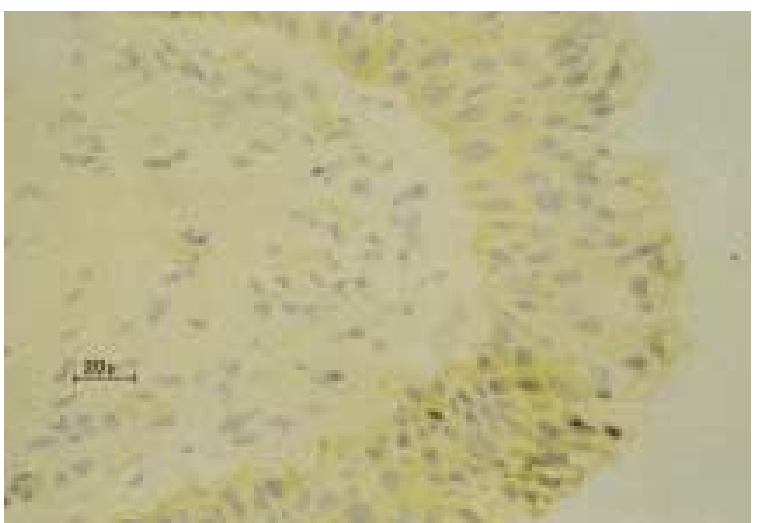

Fig. 1. - Example of positive immunostaining for $\alpha_{2} \beta_{1}$-integrin in bronchial epithelium in an asthmatic. (Scale bar=20 $\mu \mathrm{m}$ ).

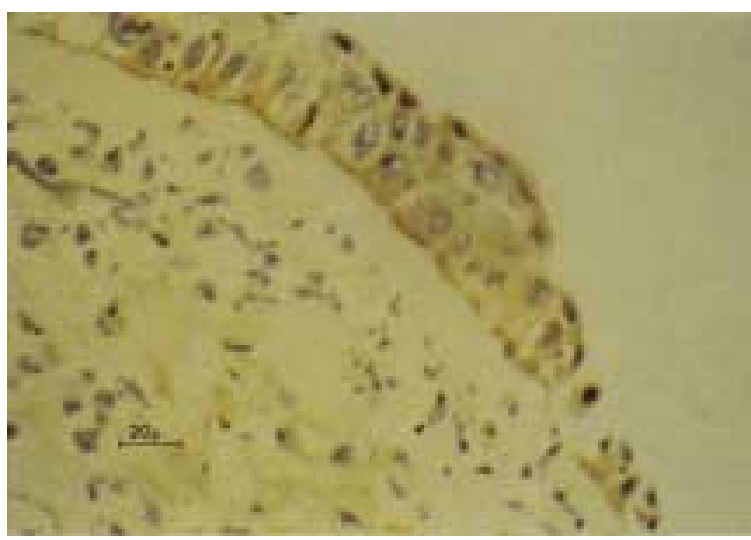

Fig. 2. - Example of positive $\alpha_{3} \beta_{1}$-integrin immunostaining in bronchial epithelium of an asthmatic. (Scale bar=20 $\mu \mathrm{m}$ )

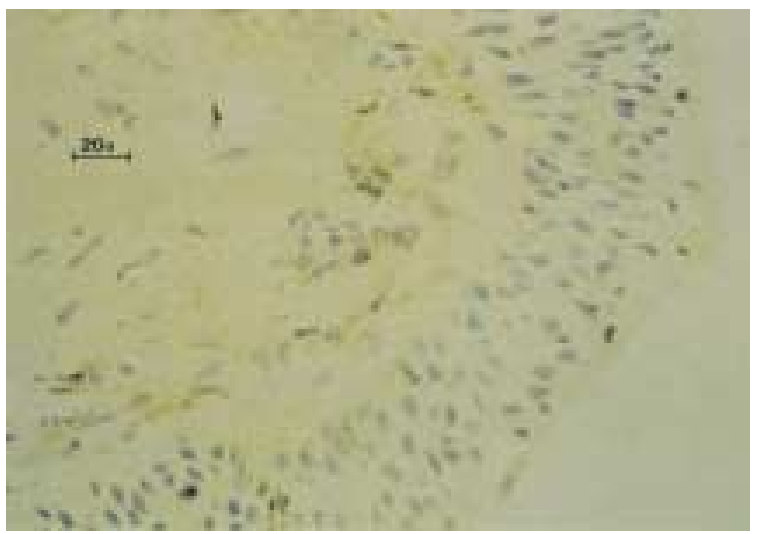

Fig. 3. - Example of $\alpha_{6} \beta_{1}$-integrin immunostaining in bronchial epithelium of an asthmatic, demonstrating positivity, particularly in the basal cells. (Scale bar=20 $\mu \mathrm{m})$.

ing for the $\alpha_{4}$-subunit and bronchial responsiveness to histamine in the asthmatics.

ICAM-1 staining was absent in bronchial epithelium of the 13 normal subjects, although present in 26 out of 33 asthmatics (one sample unevaluable). The difference was statistically significant (Chi-squared test: $\mathrm{p}<0.0001)$. Staining was variable in intensity and was generally weaker than staining of endothelial cells seen in all sections. These acted as positive "internal controls". Both

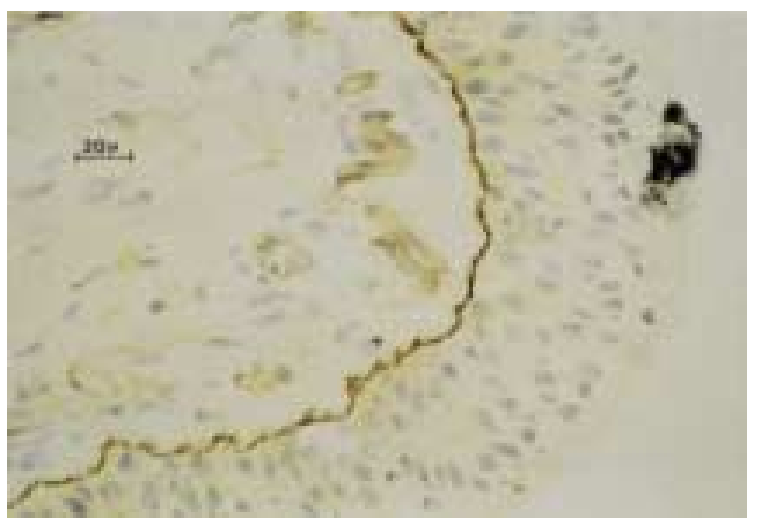

Fig. 4. - Example of $\alpha_{4} \beta_{1}$-integrin immunostaining in an asthmatic. Staining is evident in inflammatory cells in the submucosa but not in the epithelium. (Scale bar=20 $\mu \mathrm{m})$.

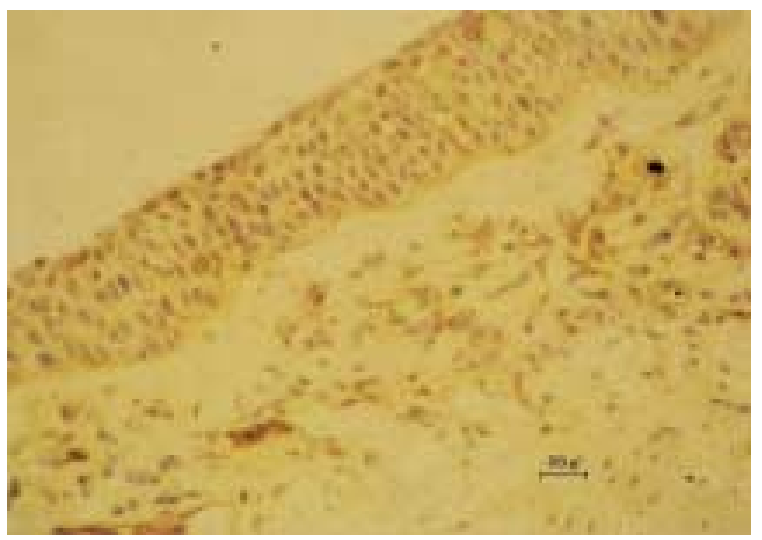

Fig. 5. - Positive immunostaining for intercellular adhesion molecule-1 (ICAM-1) in asthmatic bronchial epithelium. Note some staining of inflammatory cells and vascular endothelium in the submucosa. (Scale bar $=20 \mu \mathrm{m})$.

cell membrane and cytoplasmic positivity was identified. Some inflammatory cells also stained positively for ICAM-1 (fig. 5). ICAM-1 expression was not associated with $\mathrm{PC}_{20} \mathrm{FEV}_{1}$, nor with $\beta_{2}$-agonist consumption.

\section{Discussion}

In this study, ICAM-1 expression was found in the majority of asthmatic subjects but in none of the normal subjects. Upregulation of ICAM-1 may have a role in the inflammatory process in asthma, although it may not be a specific feature of asthmatic inflammation. Recent data from WARDLAW et al. [22] and CAMPBELL et al. [23] support our findings of increased expression of ICAM-1 in asthmatics compared to normals; whereas, MONTEFORT et al. [24] previously found no significant difference.

Inflammatory cells, particularly eosinophils, are known to infiltrate the epithelium and submucosa in severe asthma $[3,4]$ and have been reported in some mild asthmatics [12]. Although a correlation between these cellular infiltrates and the degree of bronchial hyperresponsiveness has not been demonstrated in the mild asthmatics studied, it is widely viewed that these inflammatory 
cells have an important role to play in the pathogenesis of asthma. Double immunostaining was not performed in this study, and it is, thus, not possible for us to comment on the association of ICAM-1 positivity and eosinophil infiltration.

A number of mechanisms have been suggested by which inflammatory cells may be recruited into the airway mucosa. Although the release of cytokines by various cells, including mast cells and even epithelial cells themselves, has been demonstrated [25-27] it is very likely that inflammatory cells gain access to the bronchial epithelium by more than one pathway. Adhesion of leucocytes to microvascular endothelium is required for their migration into inflamed tissues. This appears to require the binding of LFA-1 (CD18) expressed on the surface of leucocytes with its ligand ICAM-1 found on the endothelial surface, which can be blocked by monoclonal antibodies against either CD18 or ICAM-1 [8, 28]. In congenital leucocyte adhesion deficiency (LAD), in which there is a genetic deficiency of LFA-1 expression on leucocytes, there is a history of recurrent infections and, since neutrophils are unable to cross endothelium, there is an absence of pus formation [29]. In asthma, one could postulate that increased expression of ICAM-1 on endothelium could increase the adhesion of leucocytes bearing LFA-1 to the endothelium, allowing increased passage from blood into the tissues. Increased expression of ICAM-1 in the bronchial epithelium itself could increase the trafficking and maintenance of leucocytes at this site.

ICAM-1 has been shown to be the major surface receptor for $90 \%$ of rhinoviruses [30]. It is intriguing to consider that increased expression of this receptor could potentially increase susceptibility to infection with these viruses, whilst it is known that viral upper respiratory tract infections increase bronchial reactivity to histamine [31, 32].

The pattern of immunoreactivity demonstrated for the different integrin $\alpha$-subunits in bronchial epithelium is comparable with that found in other epithelial tissues, including human intestinal epithelium $[33,34]$. In general, epithelia appear to be negative for $\alpha_{1} \beta_{1}$-integrins but positive for $\alpha_{2} \beta_{1}-, \alpha_{3} \beta_{1}$ - and $\alpha_{6} \beta_{1}$-integrins. ZUTTER and SANTORO [35] showed a predominance of $\alpha_{2} \beta_{1}$ expression on ciliated columnar epithelium, particularly basally on proliferating epithelium, as in this study. DAMJANOVITCH et al. [36] showed a predominance of $\alpha_{2} \beta_{1}$ and $\alpha_{6} \beta_{1}$-integrins on normal bronchial epithelium, with weak expression of $\alpha_{1} \beta_{1}$ - and $\alpha_{3} \beta_{1}$ - and absence of $\alpha_{5} \beta_{1}$ integrins. $\alpha_{4} \beta_{1}$ was present only on leucocytes, a finding reproduced in this study. This is not suprising, as very late activation molecule-4 (VLA-4) $\left(\alpha_{4} \beta_{1}\right)$ is known to be expressed on resting eosinophils, lymphocytes and monocytes, forming an alternative means for these cells, but not neutrophils, to cross endothelium by binding to VCAM-1, a molecule found on the endothelial surface which is induced by inflammatory mediators with similar kinetics to ICAM-1 [7, 37, 38]. Immunoreactivity for the $\alpha_{5} \beta_{1}$-integrin was weak and difficult to characterize.

The lack of demonstrable differences between the asthmatics and normal subjects in expression of the $\beta_{1}$-integrins by immunohistology could be due to insensitivity of the technique, in that it is only possible to sensibly grade specimens as positive or negative. We were interested to see if there was upregulation in asthmatics due to increased epithelial activity and turnover, or decreased expression consistent with a pathogenic defect allowing epithelial loss. We have not examined the functional aspects of such receptors, and it is possible that they may be more or less active functionally, without any difference in staining being evident. It is of interest that both the $\alpha_{2} \beta_{1}$ - and $\alpha_{6} \beta_{1}$-integrins were preferentially expressed in basal epithelium, supporting a likely role for their interaction with extracellular matrix proteins of the basal lamina.

In conclusion, we were unable to detect any significant difference between asthmatics and normal subjects with regard to immunohistochemical staining for the $\alpha_{1}-\alpha_{6}$-subunits of the $\beta_{1}$-integrin family, but there was a statistically significant increase in ICAM-1 positivity in the asthmatics. ICAM-1 expression may well contribute to the recruitment of allergic inflammatory cells to the epithelium in asthma.

\section{References}

1. Beasley R, Roche WR, Roberts JA, Holgate S. Cellular events in the bronchi in mild asthma and after bronchial provocation. Am Rev Respir Dis 1989; 139: 806817.

2. Bousquet J, Chanez P, Lacoste J. Eosinophilic inflammation in asthma. N Engl J Med 1990; 323: 1033-1039.

3. Dunnill MS. The pathology of asthma with special reference to changes in the bronchial mucosa. J Clin Pathol 1960; 13: 27-33.

4. Glynn AA, Michaels L. Bronchial biopsy in chronic bronchitis and asthma. Thorax 1960; 15: 142-153.

5. Jeffery PK, Wardlaw AJ, Nelson FC, Collins JV, Kay AB. Bronchial biopsies in asthma. Am Rev Respir Dis 1989; 140: 1745-1753.

6. Lozewicz S, Gomez E, Ferguson H, Davies RJ. Inflammatory cells in the airways in mild asthma. $\mathrm{Br} \mathrm{Med}$ $J$ 1988; 297: 1515-1516.

7. Springer TA. Adhesion receptors of the immune system. Nature 1990; 346: 425-434.

8. Smith CW, Rothlein R, Hughes BJ, et al. Recognition of an endothelial determinant for CD18-dependent human neutrophil adherence and transendothelial migration. J Clin Invest 1988; 82: 1746-1756.

9. Dustin ML, Rothlein R, Bhan AK, Dinarello CA, Springer TA. Induction by IL-1 and interferon- $\gamma$ : tissue distribution, biochemistry and function of a natural adherence molecule (ICAM-1). J Immunol 1986; 137: 245-254.

10. Prober JS, Gimbrone MA, Lapierre LA, et al. Overlapping patterns of activation of human endothelial cells by interleukin-1, tumor necrosis factor and immune interferon. J Immunol 1986; 137: 1893-1896.

11. Wegner CD, Gundel RH, Reilly P, Haynes N, Letts LG, Rothlein R. Intercellular adhesion molecule-1 (ICAM1) in the pathogenesis of asthma. Science 1990; 247: 456-459.

12. Ruoslahti E. Integrins. J Clin Invest 1991; 87: 1-5.

13. Hemler ME. VLA proteins in the integrin family: struc- 
tures, functions and their role on leukocytes. Аппи Rev Immunol 1990 8: 365-400.

14. Ruoslahti E, Pierschbacher MD. New perspectives in cell adhesion: RGD and integrins. Science 1987; 238: 491-497.

15. Laitinen LA, Heino M, Laitinen A, Kava T, Haahtela T. Damage of the airway epithelium and bronchial reactivity in patients with asthma. Am Rev Respir Dis 1985; 131: 599-606.

16. Lozewicz S, Wells C, Gomez E, et al. Morphological intergrity of the bronchial epithelium in asthma. Thorax 1990; 45: 12-15.

17. Knudson RJ, Lebowitz MD, Holberg CJ, Burrows B. Changes in the normal maximal expiratory flow-volume curve with growth and aging. Am Rev Respir Dis 1983; 127: 725-734.

18. Bennett JB, Davies RJ. A comparison of histamine and methacholine bronchial challenges using the DeVilbiss 646 nebuliser and the Rosenthal-French dosimeter. $\mathrm{Br}$ J Dis Chest 1987; 81: 252-259.

19. Workshop summary and guidelines. Investigative use of bronchoscopy, lavage and bronchial biopsies in asthma and other airway diseases. J Allergy Clin Immunol 1991; 88: $808-814$.

20. Hsu SM, Raine L, Fanger H. Use of avidin-biotin complex $(\mathrm{ABC})$ in immunoperoxidase techniques. A comparison between $\mathrm{ABC}$ and unlabelled techniques. $J$ Histochem Cytochem 1981; 29: 577-580.

21. Lozewicz S, Wang J, Duddle J, et al. Topical glucocorticoids inhibit activation by allergen in the upper respiratory tract. J Allergy Clin Immunol 1992; 89: 951-957.

22. Wardlaw AJ, Bentley AM, Menz G, Storz C, Durham SR, Kay AB. Expression of the adhesion molecules ICAM-1 and ELAM-1 in the bronchial mucosa in asthma. J Allergy Clin Immunol 1992; 89: 164 (Abstract).

23. Campbell AM, Vignola AM, Chanez P, Michel FB, Bousquet J, Godard P. HLA-DR and ICAM-1 expression on bronchial epithelial cells in asthma and chronic bronchitis. Am Rev Respir Dis 1993; 148: 689-694.

24. Montefort S, Roche WR, Howarth PH, et al. Intercellular adhesion molecule-1 (ICAM-1) and endothelial leukocyte adhesion molecule-1 (ELAM-1) expression in the bronchial mucosa of normal and asthmatic subjects. Eur Respir J 1992; 5: 815-823.

25. Burd PR, Rogers HW, Gordon JR, et al. Interleukin-3 dependent and independent mast cells stimulated with $\mathrm{IgE}$ and antigen express multiple cytokines. J Exp Med 1989; 170: 245-257.
26. Cox G, Vancheri C, Otoshi T, et al. Human bronchial epithelial cell derived granulocyte macrophage colony stimulating factor (GM-CSF) prolongs survival of human eosinophils. J Allergy Clin Immunol 1990; 85: 233.

27. Denburg J, Jordana M, Gibson P, Hargreave F, Gauldie J, Dolovich J. Cellular and molecular basis of allergic airway inflammation. In: Johansson SGO, ed. Cellular Communications in Allergic Asthma. Sweden, A.W. Grafiska, 1990; pp. 15-22.

28. Barton RW, Rothlein R, Ksiazek J, Kennedy C. The effect of anti-intercellular molecule-1 on phorbol-esther induced rabbit lung inflammation. J Immunol 1989; 143: 1278-1282.

29. Marlin SD, Morton CC, Anderson DC, Springer TA. LFA-1 immunodeficiency disease. J Exp Med 1986; 164 : $855-867$.

30. Staunton DE, Merluzzi VJ, Rothlein R, Barton R, Marlin $\mathrm{SD}$, Springer TA. A cell adhesion molecule, ICAM-1, is the major surface receptor for rhinoviruses. Cell 1989; 56: 849-853.

31. Empey DW, Laitinen LA, Jacobs L, Gold WM, Nadel JA. Mechanism of bronchial hyperreactivity in normal subjects after upper respiratory tract infections. Am Rev Respir Dis 1976; 113: 131-139.

32. Laitinen LA, Elkin RB. Bronchial reactivity following uncomplicated influenza A infection in healthy subjects and in asthmatic patients. Eur J Respir Dis 1980; 106: 51-58.

33. Choy MY, Richman PY, Horton MA, Macdonald TT. Expression of the VLA family of integrins in human intestine. J Pathol 1990; 160: 35-40.

34. Richman PI, D'Ardenne AJ, Horton MA, McAulay A, Jordan S. Distribution of the VLA family of integrins in normal human tissues. J Pathol 1990; 161: 348.

35. Zutter MM, Santoro SA. Widespread histologic distribution of the $\alpha_{2} \beta_{1}$-integrin cell-surface collagen receptor. Am J Pathol 1990; 137: 113-120.

36. Damjanovitch L, Albelda SM, Mette SA, Buck CA. Distribution of cell adhesion receptors in normal and malignant lung tissue. Am J Respir Cell Mol Biol 1992; 6: 197-206.

37. Rice GE, Munro JM, Bevilacqua MP. Inducible cell adhesion molecule 110 (INCAM-110) is an endothelial receptor for lymphocytes, a CD11/CD18-independent adhesion mechanism. J Exp Med 1990; 171: 13691374.

38. Elices MJ, Osborn L, Takada Y, et al. VCAM-1 on activated endothelium interacts with the leukocyte integrin 